Vol. 19 No. 2 Th. 2019 p: 122-153

ISSN: $1411-1764$ (Print) | 2620-9446 (Online)

http://diakronika.ppj.unp.ac.id

\title{
Application Of Local Functions In Culture Melayu Arabic Of Jambi Seberang Communities As A History Learning Module
}

\author{
Apdelmi, Reka Seprina \\ Jambi University
}

\begin{abstract}
Tips, seloko, slogans, songs and ancient books are one form of local wisdom found in the people of Jambi Seberang. It an inseparable part of daily behavior from one generation to other generation. If the various local wisdoms can be managed, responded to, and developed properly, it will be a source of historical learning for students. This study use qualitative and ethnographic research methods from April to September 2019, direct field observations and documentation. The purpose of this study is to describe the form of local wisdom of Malay Arabic culture in the Jambi Seberang community. The results of this study are to produce forms of local wisdom that have been listed and documented in Seberang, Jambi City. It is hoped that the results of this study will not only be developed as learning modules but can be printed in the form of books.
\end{abstract}

Key Word : Local Wisdom, Malay Arabic Culture, History Learning Module 


\section{Introduction}

In essence, culture has values that are capable of being inherited and carried out along with the development of society. In carrying out our daily lives we cannot be separated from cultural elements, every thing we do and we do in life is greatly influenced by local culture. Culture is also used as a guide for making decisions in the fields of social, legal, economic and inherited through communication from one generation to the next, so that generations inherited have the toughness in living their lives. As stated by Geertz in (Yunus, 2014) that culture is a pattern of meaning manifested in symbols and passed down from generation to generation. In other words, culture is the work of humans who are able to produce and develop human knowledge and attitudes towards life that are inherited through communication and learning.

According to Kluchohn and Kelly in (Yunus, 2014) culture is a pattern that is used as a guideline for human behavior generated from history both implicitly and explicitly. Culture is also a product of human reason. Human life is always surrounded by culture, this is because humans always intersect with the surrounding environment, because humans always try to maintain their existence (Nadlir, 2014). Culture in the area of regionalism or ethnicity we usually know with local wisdom (Local Genius) in its sociological language is called Local Wisdom which has its own peculiarities and uniqueness without being mixed with other regional cultures. Meanwhile Keraf asserts that local wisdom is all forms of beliefs, insights and knowledge that guide humans in a community.

Tips, seloko, motto, songs and ancient books are one form of local wisdom found in the people of Jambi Seberang. These habits and values become an inseparable part of daily behavior, and become a habit that has been handed down from generation to generation until now. These values then become guidelines for everyday life and become an inseparable part (Firza, 2018). If the various local wisdoms can be managed, addressed and developed properly, it will become a source of historical learning for students.

In Minister of Education Regulation No. 22 of 2006 The Content Standards for Primary and Secondary Education Units mention that history subjects have the following competencies: (1) Understanding the values contained in a historical event, (2) Modeling and practicing exemplary leadership of historical figures in today's life, (3) Building the spirit of nationalism, unity and unity, (4) Demonstrating caring about historical heritage and evaluating historical events based on the source and interpretation of the writing. Historical learning aims to enable students to be aware of the diversity of life experiences that exist in each community and history learning also aims so that students are able to understand that history is part of everyday life. The above shows that historical learning has an important role in efforts to shape character and the application of local values for the creation of whole Indonesian people. 
Therefore, local wisdom is important to be passed on to students as the next generation of the nation's history (Leo Agung \& Wahyuni, 2013).

To study and find out what the Malay Arab community in Jambi Seberang did, why they did it and the development of local genius in Jambi Seberang, researchers used a qualitative research methodology with ethnographic methods. With ethnographi researchers must go directly and mingle with the community that will be studied, so that researchers can appreciate the reality that exists in society as well as possible (Koentjoro, 2011: 74). Furthermore, the cultural values and forms of local culture that have been identified will be applied as a source of historical learning.

\section{Method}

The research was conducted in two different places. The first place, namely in Jambi Seberang Arab Melayu Village. There will be the most important data collection on the local wisdom of Malay Arab culture. The second location is the school as a resource user learning about the local wisdom of Malay Arab culture especially in learning history. This study aims to describe the manifestation of the local wisdom of Malay Arab culture in the people of Jambi Seberang. Assess the values of local wisdom found in Malay Arab culture in the people of Jambi Seberang. Analyzing the application of local wisdom of Malay Arab culture to the people of Seberang Jambi as an alternative source of historical learning.

\section{Result}

Local wisdom has the ability to accommodate outside cultural elements. This means that the outside culture can accommodate / meet the cultural needs of the local community. This can be seen in the culture of Arab Melayu Jambi Kota Seberang. This culture is able to provide something to meet the needs of the people of Jambi Kota Seberang, both physical, spiritual and social needs. For example the gig culture carried out by the Jambi City Seberang community. This stage culture is able to meet the people's needs for their social needs. Other examples include Jambi batik, stilt houses and other home industries such as calligraphy, miniature ships, and baked crackers that meet the physical needs of the people. For spiritual needs can be taken from the culture of nisfu sya`ban, nuak, nginau, Assyura, gambus music, dance syarah funds, and zapin dance.

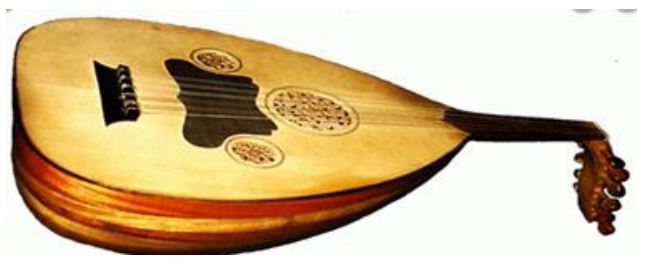

Picture 1. Gambus music

Source: Internet 
Gambus music is played by men in a row and usually gambus music is displayed to accompany the Zapin dance, Dana Syarah dance, major Islamic events, and in the wedding ceremony of the Jambi City Seberang community.

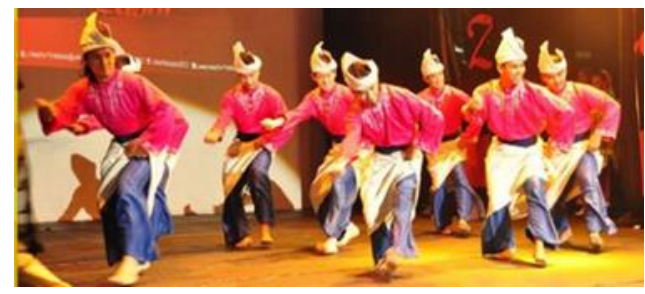

Picture 2. Zapin dance

Source: Internet

The zapin dance in Jambi, Seberang City, developed from ethnic Arab descent. This dance originating from the area of Adronomy (South Arabia), which was inherited by ethnic Arab ancestors was used as a means to spread Islam through the lyrics of zapin songs sung. The syarah dana dance is called by the Jambi community with the name bedana which means dancing a syarah fund dance. Syarah funds dance is a traditional dance performed in pairs with similar opponents.

Jambi Kota Seberang is well-known as a city of santri, also known as the center of Jambi batik making. The Jambi City Seberang batik motifs have their own philosophy and values. The background of making motifs on batik is driven by the desire to decorate objects that are used to fulfill their daily needs, including spiritual needs, the need to visualize religious symbols, aesthetic needs, and other needs according to the desired function. From the desire to decorate these objects created various forms of various Jambi City Seberang batik motifs. The Jambi City Seberang batik motif according to the Jambi Province Tourism and Culture Office has the following philosophy:

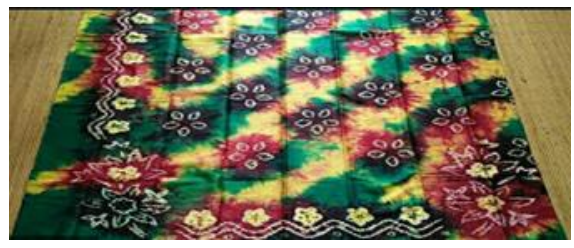

Picture 3. Tampuk Manggis

Source: Internet

Batik motifs The look of the mangosteen is interpreted as "White Heart" or the sincerity of the people of Jambi. As the traditional word "White Cotton can be seen, White heart of existence". 
Apdelmi, Reka Seprina

Application Of Local Functions In Culture Melayu Arabic Of Jambi Seberang Communities As A History Learning Module

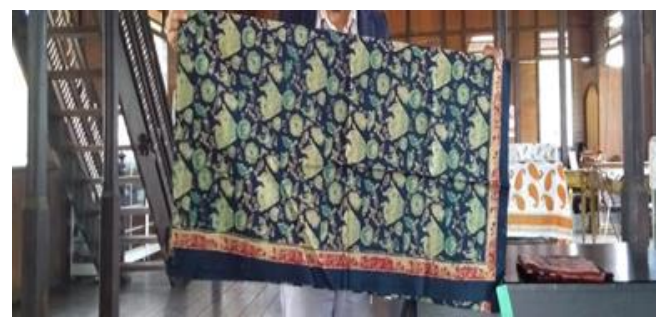

Picture 4. Kapal Sanggat (karam)

Source: Author's personal source

This motif means "sail to the island, walk to the destination" which means a warning to the social groups of the community, do not let things happen that harm yourself.

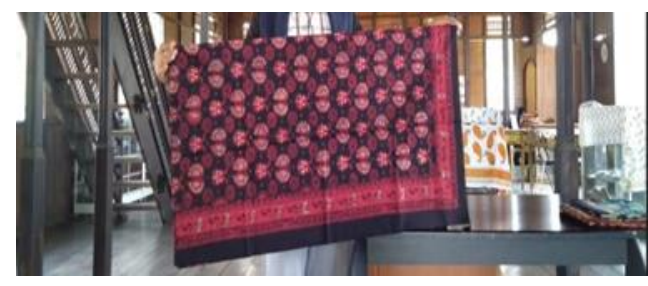

Picture 5. Durian Pecah

Source: Author's personal source

The broken durian motif has a philosophy that means leaders who have the character of trust, firm in speech, strong in their establishment and bring blessings and benefits to others and the surrounding environment.

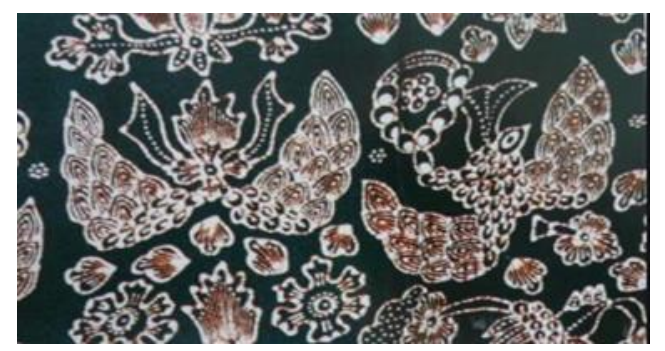

Picture 6. Merak Ngeram

Source: Author's personal source

The philosophy of the peacock motifs is the depiction of love and responsibility of a mother to her child without expecting mercy and reward services. A pregnant woman for nine months, breastfeeding, caring for and caring for children to adulthood.

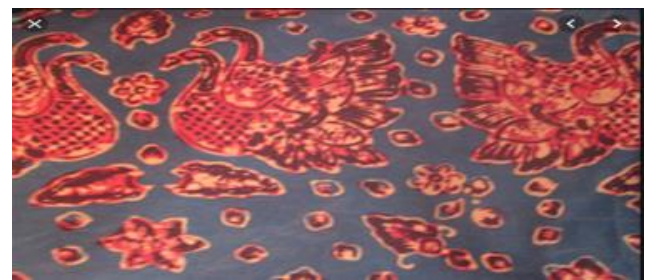

Picture 7. Angso duo

Source: Author's personal source 
This motive has the meaning of the value of harmony and gender equality, persistence, patience in effort, and harmony between human beings as glorified beings.

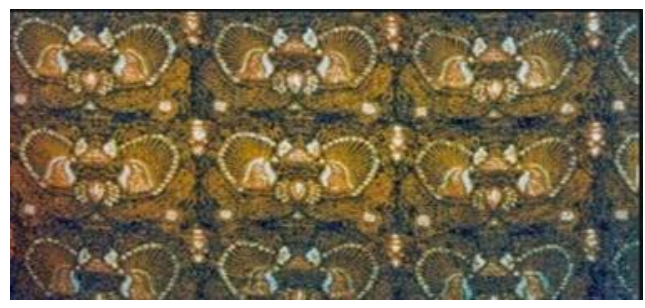

Picture 8. Kuaw Berhias

Source: Author's personal source

Decorated kuaw motif is one of the old batik motifs in Jambi Kota Seberang. This motif was inspired by a poultry animal named Kuaw. This motive is interpreted so that we always introspect ourselves to know the strengths and weaknesses that exist in ourselves, so that we can correct existing deficiencies.

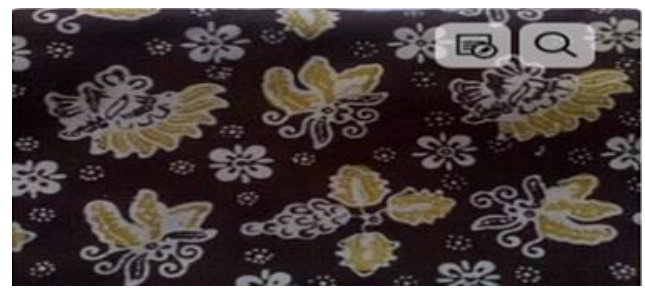

Picture 9. Riang-Riang

Source: Internet

The meaning of this batik motif is "as humans we must be able to provide benefits to other people", because the best people are the ones who provide the most benefits to others and their environment.

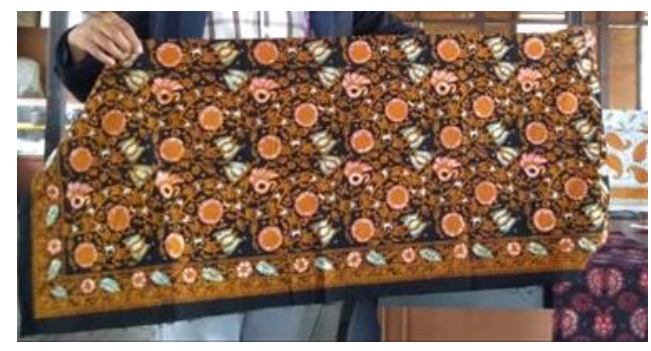

Picture 10. Batanghari

Source: Author's personal source

This Batanghari batik motif has the philosophy that human life is governed by God Almighty, Age, sustenance, failure and success of humans vary according to what has been destined. 


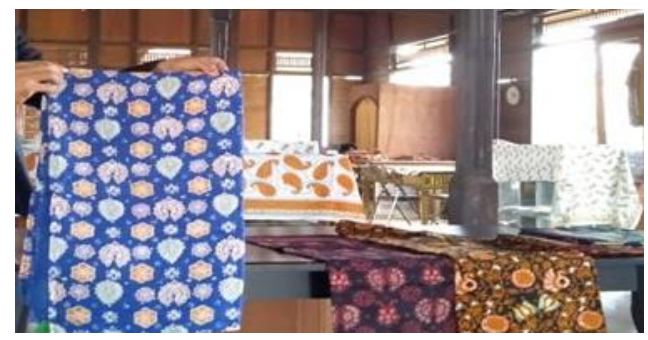

Picture 11. Kaca Piring

Source: Author's personal source

The meaning contained in the plate glass motif is a roomy and clean heart. This means that as humans we must be able to suppress the bad qualities that exist in him such as hatred, envy, jealousy, and revenge. So that we are able to develop a good quality of ourselves to the maximum.

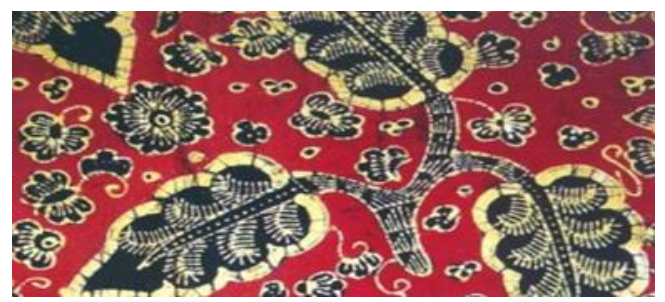

Picture 12. Daun Keladi

Source : Internet

Keladi leaf batik motifs can be interpreted as a symbol of cooperation, strong physical, loyal friends, and firm with promises. This motif also contains the advice "do not like water in taro leaves" which means it cannot be promised. Besides that the moral message conveyed through the motive of taro leaves / taro is to be a person who is steadfast, keeps promises and can be trusted.

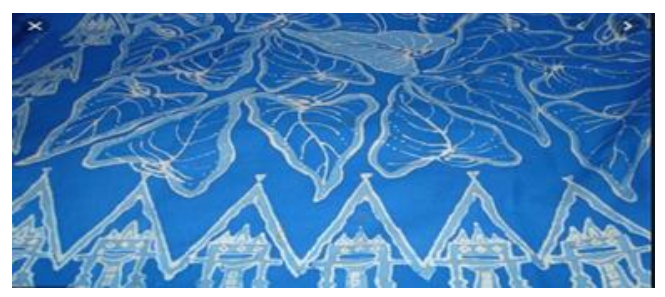

Picture 13. Relung Kangkung

Source: Author's personal source

The meaning of the kangkung niche motif, which is when problems arise in life, should be resolved immediately so that they continue to run smoothly as they should. 


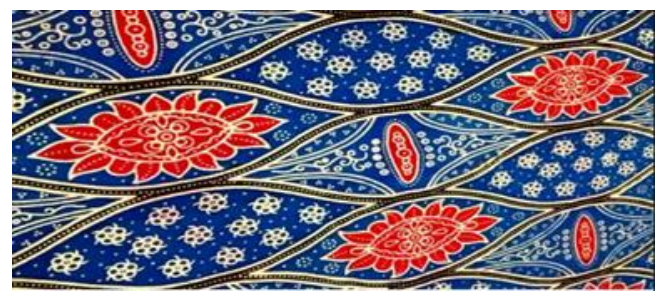

Picture 14.Bunga Tanjung

Source: Internet

Cape flower motifs have the meaning of a wise and wise leader, he said subtly, and in the attitude and behavior by the community.

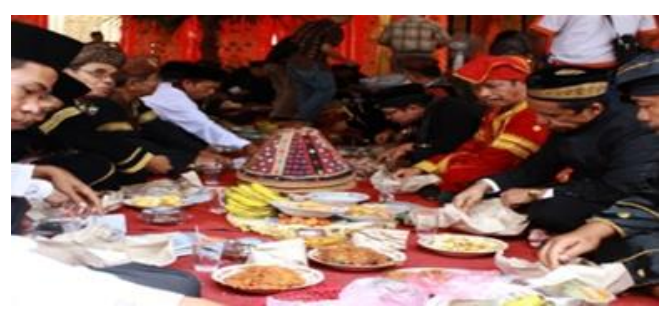

Picture 15. Eat Besamo (Eat Together)

Source: Author's personal source

The tradition of eating together has an important function in building social relations between citizens. By doing eating and drinking activities with people, it can strengthen social ties and group solidarity. The tradition of eating together is usually carried out at various events such as kenduri, rituals that are held to mark an activity, or traditional events which are usually provided by traditional foods that are characteristic of the local community.

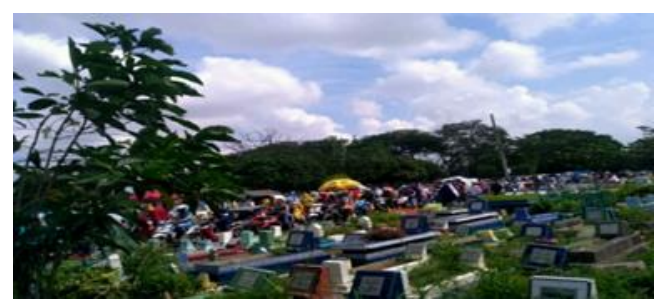

Picture 16. Mass Grave Pilgrimage

Source: Author's personal source

The grave pilgrimage is done as self-reflection and reminds us who are still alive that we will all die. We always have the negligent nature of facing death, so that sometimes people have not had time to repent and prepare themselves to face Allah SWT.

This Sya'Ban dissatisfied activity carried out by the Jambi City of Seberang community was carried out in the mosque on the night of the middle of the month of Sya 'ban on the 14th or 15th of Sya'ban after the evening prayer. The Jambi Kota Seberang community believes that Nisfu Sya 'ban night is a special night. 
Every turn of the new year of Hijriyah, the people of Jambi Kota Seberang have a culture that is thick with local wisdom. This culture is preserved by the Jambi City of Seberang community for generations. In this case the culture referred to is the day of Assyura or Syuro. Assyura is the term used to refer to the tenth day of the month of Muharram, and on the 1st to 10th of Muharram we are encouraged to fast and do good deeds.

The Malay Arab culture of the Jambi City Seberang community also experienced developments and followed the progress of the times. Bearing in mind Jambi City of Seberang is still part of the municipality, namely the City of Jambi. So we cannot deny that the elements of outside culture can enter into the life of the Jambi City Seberang community. But because of the local wisdom of Malay Arab culture, the external cultural elements that enter into the community can be filtered well. Of course the outside cultural elements that are integrated with Malay Arab culture are a good element. For example, in the performance of gambus music can be added with modern musical instruments such as drums, electric guitars, violins and piano that can add to the attractiveness of the show. The explanation above shows that Malay Arab culture has its own local wisdom. This local wisdom is of course an advantage and its values can be taken into account in life. Local wisdom is a product of the past culture that should be continuously taken into account in life, even though the culture is local but the values contained in the local culture are considered to be very universal. Local wisdom is values that are considered good and right so that they can last for a long time even to institutionalize.

Malay Arab culture that can survive for a long time has good values and can be inherited from generation to generation, so that it can be learned in life. In each culture there are different cultural values of local wisdom. Culture is not always the same for every society, because in a society there are often groups that are socially different, culturally, ethnically, religiously, and economically. Therefore, Malay Arab culture cannot be measured by other cultures. Malay Arab culture is a blend of Arabic culture and Malay culture, the Jambi Kota Seberang community is agreed upon and carried out together. Malay Arab culture is one of the cultures that exist in the Jambi Kota Seberang community that has its own values in community life. These values are:

The Malay Arab culture in Jambi Kota Seberang has agreed values and has been embedded in the local community and produced from traditions or habits, as well as symbols with certain characteristics and then become a reference for the behavior of the community. The existence of Malay Malay culture makes the younger generation aware that culture is an element of progress. This Malay Arab culture can be an example to awaken other cultures that exist around the Jambi City Seberang region so that each region has its own culture and uniqueness.

Cultural values that have been entrenched and ingrained in the Jambi City Seberang community are used as guidelines or instructions in acting in daily life. This can be seen in the custom of mutual cooperation between the Jambi City Seberang 
community in helping residents who carry out weddings or celebrations known as "manggung". So the cultural value is a driver for the community in achieving certain goals.

Character values are often ethical values. A person is said to have character or character values if he has succeeded in absorbing the values and beliefs desired by society and used as a moral force in his life (Adisusilo, 2014). Apart from prominent religious values, it turns out that Malay Arab culture also has character values. We can see the value of characters in Malay Malay culture in Jambi batik produced by the Jambi City of Seberang. In batik motifs that reflect the character of the Jambi City Seberang community. The characters in each Jambi Kota Seberang batik motif are as follows:

a) Tampuk manggis reflects the open and honest character of the Jambi Kota Seberang community. b) Kapal sanggat that has character values is careful in acting. c) Durian pecah reflects the character of the trustworthy, firm, and strong in the establishment. d) Merak ngeram that reflect the character of responsibility, and affection. e) Angso duo motives have the character value of perseverance and patience. f) The motif of Kwau berhias reflecting the character of self-reflection. g) Riang-riang that have social caring characters. h) The Batanghari motif has the value of religious character. i) Daun Keladi that reflects the character of cooperation, and is loyal to friends. j) Relung kangkung have the value of being unyielding and not easily discouraged. k) Lotus flower motifs have the character of wise and wise leaders.

This Arab Malay culture is very thick with its Islamic nuances, so religious values are the most prominent values of Malay Arab culture. In addition, Jambi City is opposite. This is in accordance with one of the traditional shops in Jambi City of Seberang which reads "adat jointed syarak, syarak jointed by Allah". This custom shows that adat in a community of Jambi City rests on the rules made, while the rules must rest on the book, the Qur'an. Almost every Malay Arab culture in the Jambi City of Seberang community has a high religious value. Religious values in Malay Arabic culture are found in the syarah fund dance, zapin dance, burdah, Nisfu Sya 'Ban, Assyura, and gambus music.

Lute music is music originating from Arabic and has been acculturated with local Malay culture. The music of gambus is Islamic music, because at the time of the musical performances of gambus songs and the poems sung are praise to Allah and the Prophet. Besides that, in the performance of gambus music, the clothes worn by the players are robe, cap or koko shirt, sarong and cap. Furthermore, the religious values found in dances such as the Dana Syarah and Zapin dance are the polite and neat ways of dressing the dancers and the music and song lyrics sung to accompany this dance are praises to Allah who created the universe and praise to the Prophet Muhammad who had brought the teachings of Islam. At the time of the day the Assyura community of Jambi City of Seberang fasted and gave alms to orphans and the needy. At the time of the disaster and the outbreak of the disease, the people of Jambi Kota Seberang will jointly read the burdah to reject the disaster. In Malay Malay culture, people are invited 
to obey what is ordered by religion and stay away from what is forbidden by religion. Malay Arab culture has valuable religious values that can be applied in daily life.

Malay Arab culture also has an Islamic background. Art is a beauty created by a person or group of people. The art in question is the art of music and dance. The art of music that exists in Malay Arabic culture is gambus music, while dance is a syarah fund dance and zapin dance. The zapin dance is used as one of the social gatherings of the Jambi City Seberang community. Dana syarah dance is used as entertainment, and association between Habib, Sayyid, and other Arab descendants, and while gambus music is the accompaniment of zapin dance and syarah funds dance. We can see the family values that exist in the Jambi City of Seberang community from the attitude of the people who always want to maintain friendship with fellow citizens as well as those who come there. The existing culture and religious traditions are always carried out by the local community together. Even this was also seen at the time of the grave pilgrimage, the community was in tandem with relatives and family coming to the funeral for a pilgrimage. In addition, this grave pilgrimage can strengthen the relationship at the time of mutual cooperation to clean the wild grass around the tomb. To clean the public cemetery in the Kelurahan, the Jambi City of Seberang community carried out mutual cooperation not only the graves of their relatives were cleaned up, but the other graves were also cleaned that day.

Based on the explanation above, an illustration of the value of the local wisdom of the Malay Arab culture of the Jambi City Seberang community can be passed on to the younger generation. Inheritance of these values can be done through various activities in the community, including through the education process in schools. In the form of learning and extracurricular activities, especially through the process of integration in learning Islamic Cultural History. The value of local wisdom is implemented by the Jambi City Seberang community in daily life and actualized in a variety of cultural events and religious traditions that are still preserved. The Jambi city of Seberang has an awareness that the existing culture and tradition must be passed on to the younger generation even though the younger generation is now starting to leave the local culture as an identity. Cultural identity is a characteristic of the community that shows its identity with the values of local wisdom. 


\section{References}

Adisusilo, S. (2014). Pembelajaran Nilai Karakter. Jakarta: PT Rajagrafindo Persada.

Firza. (2018). No Integration of Conflicts Resolution Values in Learning of History: a Case Study in KerinciTitle. Yupa: Historical Studies Journal, 2, 33-43.

Leo Agung, S., \& Wahyuni, S. (2013). Perencanaan pembelajaran sejarah. Yogyakarta: Ombak.

Nadlir, M. (2014). Urgensi Pembelajaran Berbasis Kearifan Lokal. Jurnal Pendidikan Agama Islam (Journal of Islamic Education Studies), 2(2), 299-330.

Yunus, R. (2014). Nilai-nilai kearifan lokal (local genius) sebagai penguat karakter bangsa: Studi empiris tentang Huyula. Yogyakarta: Deepublish. 